\title{
School Leadership Master's Program Enhancement through Cross-Border Collaboration between Assiut and Kuwait Schools of Education
}

\author{
Hanan El Halawany \\ Assuit University, \\ El Fateh, Assiut Governorate, \\ 71515, Egypt \\ Munirah AlAjmi \\ Kuwait University, \\ Al-Shadadiya, Kuwait
}

DOI: https://doi.org/10.36941/jesr-2022-00o7

\section{Abstract}

Egypt and Kuwait are currently executing a large-scale transformation in the national education system. On such time, school leadership capacity building and development is crucial and fundamental. Therefore, the current research seeks to scrutiny leadership components presented in the Education Administration Master program offered in Assiut and Kuwait Faculties of Education to cross match the presented knowledge and competencies with international requirements of highly credited leadership master programs. A comparative analytical study was implemented to compare the leadership models presented in the Assiut and Kuwait master's programs in educational administration. The intended outcome is to enhance the current master program offered in both faculties.

Keywords: Educational leadership, Egypt, Kuwait, master's programs, comparative study, faculties of education

\section{Introduction}

The $2 \mathbf{2}^{\text {st }}$ century educational scholarly arena is increasingly understanding school leaders' role in ensuring high performance in schools. School leaders are responsible for promoting success in schools, including improving the achievement levels of students and enhancing the overall quality of the education process. A large segment of educational literature has proved that school leaders influence students' learning substantially by directing and supervising teachers' performance (Bush et al., 2011; Huggins et al., 2016; Jackson \& Marriott, 2012).

Consequently, school leadership has become a highly qualified profession that requires extensive preparation, rather than positions offered based on experience. Bush (2010) indicated four reasons for this dynamic shift in the perception of school leadership: 1) the complexity of the role of school leaders in schools in the $21^{\text {st }}$ century, 2) the growing complexity of the school context, 3 ) the diverse competencies school leaders need to acquire to lead effectively; 4) Leading is an ethical obligation. Consequently, school leaders need to be informed about what to expect. School leadership 
has become very demanding. It requires responding to and interacting with expectations from different and diverse parties such as students, teachers, parents, and the local community.

Egypt and Kuwait are currently executing large-scale transformations in the national education system. Fullan (2006) suggested that during change, developing school leadership capacity is fundamental for building consensus among teachers to achieve the new school vision, uniting efforts to fulfill common goals, and minimizing resistance to new changes. Therefore, many researchers highlight the fact that leadership capacity building is the main pillar of school improvement (Bush, 2010; Huggins et al., 2017; Kelley et al., 2005; Leithwood et al., 2004).

\subsection{Rationale and Research Objectives}

Egypt and Kuwait consider a teaching certificate and teaching experience the only qualifications for school leadership positions. Consequently, they both face an extreme and grave shortage of qualified school leaders (Abd El Razek, 2019; Bush et al., 2011; Khondker, 2004). Adly (2006) took this dilemma to a more profound level by accusing the educational bureaucratic authority of attempting to preserve power and capital in its hands, and limiting leadership positions to those who can only reproduce the existing unjust leadership hierarchy.

The current research aims to achieve the following:

1. Reviewing the required school leadership model during school transformation in Egypt and Kuwait

2. Scrutinizing leadership gaps in the current Master of Educational Administration programs offered in the Assiut and Kuwait Faculties of Education

3. Comparing top-ranked universities offering Master programs in education leadership with a special focus on education transformation and school improvement to extract the targeted leadership knowledge and competencies.

4. Introducing a theoretical framework for enhancing the Master program in Educational Administration offered in both Assiut and Kuwait Faculties of education.

\subsection{Research Significance}

This research is considered a pioneer cooperative effort between Egyptian and Kuwaiti scholars who aim to scrutinize the gaps in the Master of Educational Administration programs offered in the Assiut and Kuwait Faculties of Education considering current trends and models in the school leadership literature. Their efforts evolved in terms of proposing a framework for an enhanced master's program based on the analysis of educational leadership programs offered in top 10 ranked university globally.

\section{Research Procedures and Methodology}

To achieve research objectives, we must understand the current educational scene, especially considering the ongoing transformation process. New international learning standards with higher expectations are being adopted in both Egyptian and Kuwaiti education system which implies that school leadership requires profound transformation and redesigning, rather than instant administration performance remedies. School leaders are expected to master and perform several leadership competencies (e.g., organizational transformation and locating unconventional fund revenues) to improve teaching and learning practices. To achieve these goals the study will evolve based on the following procedures:

1. Conducting a comparative analysis of leadership models presented in the Education Administration Master's program offered in the Assiut and Kuwait Faculties of Education

2. Identifying leadership models required during the education transformation and school improvement phase.

3. Comparing top-ranked universities offering master's programs in education leadership with a 
special focus on education transformation and school improvement.

4. Introducing a theoretical framework for enhancing the current educational administration master program that is offered in both Assiut and Kuwait Faculties of Education.

This study's evolutionary course defines its comparative nature. In his seminal work, Teichler (1996) argued that the comparative education notion in the field of higher education encompasses systematically addressing the "phenomena of higher education in more than one "culture," "society," or "nation" or in a single one in a comparative perspective. He further states that it pursues identifying common elements and differences as well as testing hypotheses on causal relations" (pp. 448-449).

In comparative studies, researchers encounter a serious dilemma concerning the selection of cases for comparison. Sartori (1970) argued that comparative education researchers' ability to conduct a satisfactory and coherent study depends on their ability to select cases. If they select two cases with no common shared elements, there will be no room for comparability. Contrarily, if they choose two identical cases, there will be no reason to conduct a comparison. He explains that the best cases for selection are those that are "similar enough" (p. 1035). This study shows that Egypt and Kuwait's master's program in Education Administration share common elements while encompassing other elements of differentiation. Therefore, we focused on these two programs.

\section{Literature Review}

To fill gaps in the current master's program in Education Administration offered in both Assiut and Kuwait Faculties of Education, two approaches were adopted: The first identifies the most appropriate leadership models required during time of transformation; the second analysis educational leadership master's programs offered in the top 10 ranked universities globally.

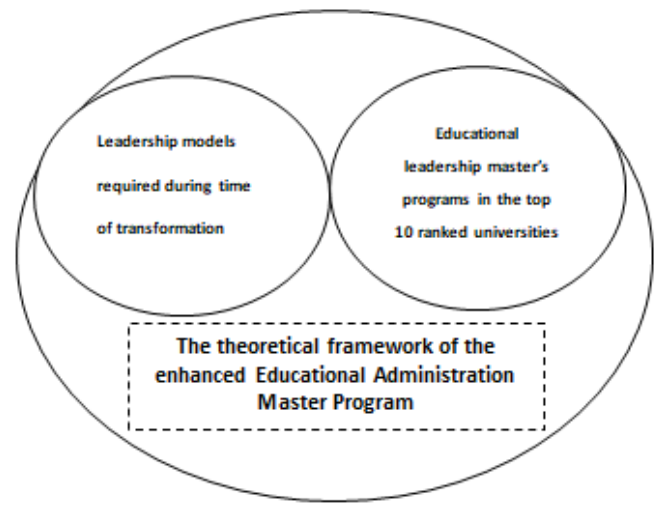

Figure 1: The founding basis for the theoretical framework of the enhanced Educational Administration Master Program

\subsection{The required school leadership models during transformation}

Although educational reform in Egypt and Kuwait follows two different paths regarding intensification and restructuring, both aim to accomplish systemic and far-reaching changes by implementing international standardized tests, and close and exhaustive monitoring intensifying what and how teaching is delivered using innovative interactive methodologies aimed at improving student learning. This reconstruction process involves school instructional performance, teachers' academic performance, collaborative work, and reorganizing schedules to support students' progress (Beatty, 2007; Fullan, 2006).

To translate these expectations into practice, a shift from traditional hegemonic politically 
oriented leadership to a far more egalitarian, democratic, and distributive leadership is essential. This shift will defy the status quo of school leaders and teachers dragging them out their comfort zone, especially those who are bystanders, as they will be pressured to participate in making critical decisions, share in new knowledge formulation, and undertake new responsibilities. In short, a series of challenges is expected to shift school transformation efforts, such as complex emotional meaningmaking processes associated with maintaining the status quo that can either inhibit or drive smooth transformation. Contrarily, schools might experience burnout during the reconstruction and transformation of curricula activities, professional responsibilities, and roles of staff and students.

At this critical stage, new educational and professional outcomes must evolve to serve as a link between the standards of practice for high-performing school leaders and formal educational programs responsible for preparing and training competent leaders. These programs should be designed to develop impactful school leaders who can oversee the transformation process. Upon this rational the current research is developed within the comparative scholarly discourse to export international experiences, customizing them to fit the Egyptian and Kuwaiti contexts. A study conducted by the Pennsylvania Department of Education in 2013 assessed school leaders' performance and explored how they affect school change and school improvement. Data were collected from 336 principals and 69 assistant principals. Their study's results confirmed that an effective school leadership practice during transition should be grounded on "strategic/cultural leadership, systems leadership, leadership for learning and professional, and community leadership" (McCullough et al., 2016; Teh et al., 2014). Therefore, the prospective leadership master's program that this study needs to configure should encompass the following domains:

1. Instructional leadership

2. Distributed leadership

3. Organizational leadership

4. Cultural leadership

5. Human resource leadership

\subsection{Instructional leadership}

The instructional leadership concept was significantly influenced by research that claimed that effective schools have principals who stress the significance of educational leadership. Instructional leadership suggests that setting clear objectives, a learning environment free from any type of noise, smart goals for better school performance, and setting high expectations for students and teachers can drive success. According to Hallinger (2005), an instructional leader's mindset tends to encompass a strong moral purpose that focuses on promoting in-depth learning, trusting relationships, professional inquiry, and making data-informed decisions. Therefore, an instructional leader considers everyday institutional management tasks that are responsible for creating a secure and safe learning environment, effective teaching performance, suitable intervention for students in need, and supporting teachers with genuine appreciation and emotional intelligence.

While transformational leadership is the most common model in education (Webb, 2014), the impact of instructional leadership on the learning outcomes of students tends to be greater (Leithwood \& Sun, 2012). Researchers show that high-performing schools have instructional leaders that focus on enhancing a positive learning environment, managing curricula and teaching, defining the school mission, monitoring and observing instruction, and assessing instructional programs (Jackson \& Marriott, 2012; McEwen, 2019). Consequently, leading instructional effort in schools is considered school leaders' prime role.

\subsection{Distributed leadership}

This theory originated from the field of psychology. This suggests that leadership is a group trait rather than an individual characteristic. This model has been approved by educational academics and 
practitioners as the traditional "great man" theory is considered unrealistic and difficult to attain. Contrarily, distributed leadership suggests that shared patterns of action, communication, and decision-making among teachers and school leaders improve the performance of teachers and students (Leithwood, 2009; Leithwood et al., 2009).

A distributed leadership perspective suggests that multiple individuals can exchange leadership roles (Harris, 2004; Harris \& Spillane, 2008). It focuses on how leadership influences the improvement of organizational and instructional processes (Spillane et al., 2004). Educational scholars define distributed leadership as the interdependence of the environment and an individual, showing how human activity is dispersed in a shared web of artifacts, actors, and situations in learning practice (Leithwood et al., 2004). School leaders are expected to adopt this model easily as it allows them to share and surrender power to talented members who believe in and adapt their vision and goals.

According to Harris and Kemp-Graham (2017), to ensure effective performance of distributive leadership, school leaders need to build a trust-based culture in which teachers are content enough to cooperate in undertaking leadership responsibilities. Therefore, distributive leadership is a form of shared leadership that takes the form of a continuous interactive cycle among teachers, leaders, and the school environment. Within this cycle, the school leader is expected to perform diverse roles as counselors, teachers, principals, and sometimes students.

Distributed leadership is highly reputed in the field of education owing to its genuine normative power in responding to changes and transformation in schools. During transformation, schools tend to restructure leadership teams to fulfill their emerging needs.

\subsection{Organizational leadership}

A successful school leader develops the school as an effective organization that supports and sustains the performance of teachers and students. This is manifested by strengthening school culture, as school leaders significantly influence organizational culture through practices geared toward accomplishing common goals, beliefs, values, and attitudes promoting mutual care and trust among school members (Schein, 2013).

School leaders redesign organizational structures through transformations in personnel and job allocations, rescheduling, designing time and space, regular procedures, operations, and integrating technology into the administration system (Leithwood \& Riehl, 2003); all these can hinder or drive individual performance to accomplish organizational goals. Successful school leaders navigate organizational changes to establish positive systems so that teachers can constantly improve their performance and expand their learning experiences (Huggins et al., 2016, 2017).

Simultaneously, school leaders work to enhance school performance by building a collaborative process in which the school staff can be involved in the decision-making process. Such involvement empowers school staff and drives them to believe in their ability to change and reconstruct organizational contexts to meet their needs and goals (i Solà et al., 2016; Kelley et al., 2005).

\subsection{Cultural leadership}

Gantasala and Omar (2016) emphasized that an organization's performance is influenced by its culture. Schools, as organizations, look up to the most influential leaders who can help them develop. School leaders help shape the culture of schools (Sturgis et al., 2017). Cultural school leadership is described as the ideology, perception, and system of assumptions that the school leader transfers to teachers, students, and staff, and the values that give the school its unique identity.

Solomon and Steyn (2017) explained that cultural leadership grasps varied cultural perspectives. First, cultural leadership can be effective when leaders develop a multicultural mindset. Second, a cultural leader should be able to work with distinct people from different cultures, and third, work collaboratively with teachers to exchange information and experiences (Williams, 2018). Price (2017) described a school leader as an active, entrepreneurial, generous, and public social agent practicing 
cultural leadership in its three dimensions.

During transformation, school leaders construct the right culture that stimulates change by adopting a collaborative culture that impacts the efficiency and effectiveness of various staff members (Tsivgiouras et al., 2017). School leaders should be transformational rather than transactional, as they need to form and assess the appropriate culture that inspires and fosters change by developing a shared vision that unites students, teachers, and the community toward accomplishing common goals (Leithwood and Sun, 2012).

\subsection{Human resources leadership}

In several contexts, we emphasize that school leaders affect students' achievement directly. However, this effect is transmitted through teachers; school leaders influence teachers directly, who consequently shape students' learning and academic achievement. A school leader ensures that the school has educators committed to working collectively to ensure that their learners achieve appropriate results (Clark, 2017).

A professional learning community provides shared and supportive leadership to implement a positive learning culture with a shared purpose. In leading human resources in schools, school leaders should ensure that the school functions as a learning community where administrators and teachers work collectively to improve learning at all costs. Schools should develop and offer opportunities that encourage leadership roles, staff interactions, and professional development opportunities (Carpenter, 2015).

A human resources leader should plan for the de-privatization of how the school operates and builds staff capacity for better results. They should establish a shared educational vision and incorporate trust-building activities among teachers, as shared values and vision help schools create a suitable learning environment.

In conclusion, this section discusses and analyzes school leaders' roles and responsibilities in the $21^{\text {st }}$ century during transformation. As Crow and Møller (2017) delineated, the dynamic nature of schools in the $2 \mathbf{1}^{\text {st }}$ century emphasizes complexity rather than routinization, where teachers, the staff, and students must work closely and make multiple decisions without the close supervision of school leaders. Additionally, the extensive dependence on technology and significant changes in instruction forms requires school leaders to acquire new skills. Within this context, the importance of appropriate and adequate preparation of prospective school leaders emerges as a necessity for preparing and training school leaders in the $21^{\text {st }}$ century. In Egypt and Kuwait, education faculties are responsible for fulfilling this mission of preparing and training competent prospective school leaders (NCATE, 2008, p. 18).

\section{A Comparative Analysis of Leadership Models Presented in the Administration Master's Programs of Assiut and Kuwait Education}

\subsection{Assiut Master of Educational Administration program}

The Master's in Comparative Education and Educational Administration program is one of the two master's programs that the Foundations of the Education Department offers. The program does not have an independent vision or mission but is expected to achieve the faculty's mission of being "An accredited college dedicated to preparing a creative, competent teacher who is capable of keeping pace with technological development, modern trends in teaching and learning present and future, and excellent in educational research, through upgrading the faculty's programs and its various units, and developing and implementing training and research programs that contribute in developing the surrounding community and function with the University ideological framework" (Assiut University, 2016).

The first year is crucial as it encompasses courses that aim to enhance the academic undergraduate degrees of students, focusing on a profession in the field of educational administration. The courses are considered an excellent opportunity for teachers that seek to capitalize on their skills and knowledge in the field of educational administration. They also create an opportunity for candidates to tackle complex material and complete challenging assessment tasks 
that enhance their ability to practice different intellectual and practical skills (e.g., problem-solving, critical thinking, scientific thinking, and research design). These courses were distributed between the two semesters. Table 1 illustrates the study plan.

Table 1: The first-year study plan in the Master's in Comparative Education and Educational Administration program

\begin{tabular}{|c|c|c|c|}
\hline Semester & \begin{tabular}{|c|} 
Course \\
code
\end{tabular} & Title of course/s & $\begin{array}{l}\text { Credit } \\
\text { Hours }\end{array}$ \\
\hline \multirow[t]{3}{*}{ First } & Edu.707 & $\begin{array}{l}\text { The student selects one course: } \\
\text { - Contemporary Systems of University Education } \\
\text { - Contemporary Systems of Pre-university Education }\end{array}$ & 3 \\
\hline & Edu.708 & $\begin{array}{l}\text { The student selects one course: } \\
\text { - Educational Institution Accountability and Performance Assessment } \\
\text { - Contemporary Administrative Ideology and Its Application }\end{array}$ & 3 \\
\hline & Edu.709 & - Seminar & 3 \\
\hline \multirow[t]{3}{*}{ Second } & Edu.710 & $\begin{array}{l}\text { The student selects one course: } \\
\text { - International Issues in Education } \\
\text { - Studies in Comparative Education }\end{array}$ & 3 \\
\hline & Edu.711 & $\begin{array}{l}\text { The student selects one course: } \\
\text { - Educational Administration in a Changing World } \\
\text { - Organization Enhancement in the Field of Education }\end{array}$ & 3 \\
\hline & Edu.712 & - Seminar & 3 \\
\hline
\end{tabular}

\subsection{Kuwait Master's in Educational Administration program}

The Master's in Educational Planning and Administration program is among the five master's programs offered by the College of Education at Kuwait University. The program was offered by the Department of Educational Administration and Planning. It is a three-year program with 39 credit hours. The first two years are dedicated to completing course work, during which the students undertake 13 courses in a span of four semesters; the final year is dedicated to thesis work. Courses are divided into cores and electives. Core courses include educational supervision (advanced), educational planning, organizational behavior, higher education management, educational communication, and economics of education. These courses were offered by the Department of Educational Administration. Other core courses covering subjects such as educational research methods and inferential statistics in education, and a project course, are offered by other departments; all graduate program candidates, regardless of their major, must complete them. The last four courses are electives, among which students may select educational management sciences, educational development management, comparative education, descriptive statistics, and their applications using the Statistical Package for Social Sciences (SPSS) and Curriculum Development (Theory and Practice). At the end of the course work, students must appear for a comprehensive exam to proceed to thesis work. Table 2 illustrates the program's study plan.

Table 2: The study plan for the Master's in Educational Administration and Planning program

\begin{tabular}{|c|c|c|c|c|}
\hline \multirow{2}{*}{ Type of courses } & $\begin{array}{c}\text { Course } \\
\text { code }\end{array}$ & Title of course/s & $\begin{array}{c}\text { Credit } \\
\text { Hours }\end{array}$ \\
\hline \multirow{3}{*}{ Core courses (9 credits) } & $0830-503$ & $\bullet$ Educational Research Methods & 3 \\
\cline { 2 - 5 } & $0830-505$ & $\bullet$ Inferential Statistics in Education & 3 \\
\cline { 2 - 5 } & $0810-593 \cdot$ Project & 3 \\
\hline
\end{tabular}




\begin{tabular}{|c|c|c|c|}
\hline Type of courses & $\begin{array}{c}\text { Course } \\
\text { code }\end{array}$ & Title of course/s & $\begin{array}{l}\text { Credit } \\
\text { Hours }\end{array}$ \\
\hline \multirow{6}{*}{$\begin{array}{l}\text { Specialization } \\
\text { ompulsory } \\
\text { courses (18 credits) }\end{array}$} & o810-501 & - Educational Supervision (Advanced) & 3 \\
\hline & $0810-527$ & - Educational Planning & 3 \\
\hline & $0810-528$ & - Organizational Behavior & 3 \\
\hline & o810-541 & - Higher Education Management & 3 \\
\hline & $0810-542$ & - Educational Communication & 3 \\
\hline & o810-548 & - Economics of Education & 3 \\
\hline \multirow{5}{*}{ Electives ( 12 credits) } & o810-516 & - Educational Management Sciences & 3 \\
\hline & $0810-543$ & - Educational Development Management & 3 \\
\hline & $0810-525$ & - Comparative Education & 3 \\
\hline & $0810-501$ & - Descriptive Statistics and Its Applications Using SPSS & 3 \\
\hline & $0840-516$ & - Curriculum Development (Theory and Practice) & 3 \\
\hline Thesis & $200-599$ & - Thesis & \\
\hline
\end{tabular}

Table 3: Comparison between Master's in Educational Administration programs in Assiut and Kuwait

\begin{tabular}{|c|c|c|}
\hline $\begin{array}{c}\text { Area of } \\
\text { comparison }\end{array}$ & Assiut & Kuwait \\
\hline Program title & $\begin{array}{l}\text { Comparative Education and Master's in Educational } \\
\text { Administration Program }\end{array}$ & $\begin{array}{l}\text { Master's degree in Educational } \\
\text { Administration and Planning. }\end{array}$ \\
\hline Vision & No independent vision & No independent vision \\
\hline Mission & $\begin{array}{l}\text { Consents to the mission of the faculty of education: "An } \\
\text { Accredited college dedicated to preparing a creative, } \\
\text { competent teacher who is capable of keep pace with } \\
\text { technological development, modern trends in teaching and } \\
\text { learning, present and future, and excellent in educational } \\
\text { research; through upgrading the faculty's programs and its } \\
\text { various units, and developing and implementing training and } \\
\text { research programs that contribute to developing the } \\
\text { surrounding community and function with the University } \\
\text { ideological framework" (Assiut University, 2016). }\end{array}$ & $\begin{array}{l}\text { It has an independent mission: "providing } \\
\text { learners with the knowledge foundations for } \\
\text { the program's specialization and the } \\
\text { necessary skills in the research aspects and } \\
\text { the values required to practice it, in addition } \\
\text { to qualifying the preparation of leaders that } \\
\text { promote the educational field efficiently and } \\
\text { effectively." }\end{array}$ \\
\hline Program type & Semester & Credit hours \\
\hline \begin{tabular}{|l|} 
Specialized \\
courses
\end{tabular} & $\begin{array}{l}\text { School Administration Theory, School Administration in } \\
\text { Practice: Six courses focus on school administration theories } \\
\text { and their applications. The courses are Contemporary System } \\
\text { of University Education, Contemporary System of Pre- } \\
\text { university Education, Contemporary Educational Institution } \\
\text { Accountability and Performance Assessment, Contemporary } \\
\text { Administrative Ideology and Its Application, Educational } \\
\text { Administration in a Changing World, and Organization } \\
\text { Enhancement in the Field of Education. } \\
\text { Research methodology: One course presented in the } \\
\text { program regarding methods in research (Seminar). } \\
\text { Supporting fields: Two courses on international comparative } \\
\text { studies-Studies in Comparative Education and International } \\
\text { Issues in Education. }\end{array}$ & $\begin{array}{l}\text { School Administration Theory: Four } \\
\text { courses on school administration theories- } \\
\text { educational supervision, organizational } \\
\text { behavior, theories of educational } \\
\text { administration, and economics in education. } \\
\text { One course (Educational development) } \\
\text { integrates theoretical aspects with practice. } \\
\text { School administration in practice: Three } \\
\text { courses focused on practical aspects of } \\
\text { educational administration (Administration } \\
\text { of Higher Education, Educational Planning, } \\
\text { and Educational Communication). } \\
\text { Research methodology: Three courses on } \\
\text { research methods-educational research } \\
\text { methods, inferential statistics in education, } \\
\text { and descriptive statistics and its applications } \\
\text { using the SPSS } \\
\text { Supporting fields: Two courses on } \\
\text { supporting fields-curriculum development, } \\
\text { theory and practice, and comparative } \\
\text { education, are taught in other departments, } \\
\text { such as Education Foundation and } \\
\text { Curriculum. }\end{array}$ \\
\hline
\end{tabular}

By comparing the data and components of both the Assiut and Kuwait Master's in Educational Administration programs, it can be argued administration, not leadership, is the core concept and 
philosophy upon which the two programs are constructed. This conclusion is deduced from the examination of the course titles and descriptions.

Course descriptions are not inclusive and are abbreviated liberally in both programs. Both programs lack a fully detailed syllabus. An accountable and correct syllabus must contain course information, instructor information, a brief but inclusive one-paragraph course description, course learning outcomes, aligned program learning outcomes and competencies, required texts, assessment and evaluation criteria, learning activities, homework and assignments, and a course timetable.

Neither program is independent, as neither has its own vision. Each abide by its faculty's vision, which clearly states that its core vision revolves around fostering a competent teacher-neither educational leaders nor administrators. However, the Kuwaiti program has its own mission, which explicitly declares its commitment to preparing candidates to be competent practitioners and researchers in their field of specialization. The Kuwaiti program's title clearly states that it is dedicated to the field of educational administration, while the Assiut program integrates two majors, comparative education, and educational administration.

While both programs share many common features, the Kuwaiti master's program offers a broader diversity of courses than that of Assiut, as course work in Kuwait lasts two consecutive years. Consequently, graduation requirements differ despite spanning the same duration. In the Assiut program, students are required to finish one year of course work, write a thesis, and defend it at the end of the third year; in Kuwait, students are required to finish two years of course work, pass a comprehensive exam, and write a thesis and defend it by the end of the third year.

However, the comparative study revealed that the absence of addressing leadership issuesconceptually or practically-is a crucial common feature shared in Assiut and Kuwait Master's in Educational Administration programs, and it deforms both programs. Therefore, they both fail to transform the image of the principal from an authoritative director to a more egalitarian, autonomous leader who can delegate and share leadership. Recent reforms in the Egyptian and Kuwaiti education systems strongly emphasize the need for leaders who can motivate, change, inspire, and energize teachers, students, and administrative staff by transforming schools into sustainable learning communities focused on teaching and learning. Thus, they are held accountable for promoting in-depth learning and students' academic performance. Simultaneously, they are responsible for creating a vision that all stakeholders share and do their best to fulfill. Meanwhile, they are expected to share and surrender power to others who can actively implement the required changes. In short, they are no longer considered managers or directors but rather leaders who perform multiple and sometimes conflicting roles as a counselor, teacher, principal, and student.

\section{Educational Leadership Master's Programs Offered in the Top ro Ranked Universities Globally}

Leadership studies stress the importance of encouraging novice teachers to develop leadership capacity and undertake leadership roles early. They assert that initial teacher education programs play a key role in preparing future school leaders (Acquaro, 2019; Harris \& Jones, 2019).

The proposed program is elicited from the examination of the top 10 universities that offer master's programs in educational leadership in 2020 (QS Top Universities, 2020) and the results generated from the above comparative descriptive study. An audit of the offered master's programs was conducted in February 2021. This revision helped resolve the first controversial issue concerning the nature of the intended leadership master's program, arguing that it will focus on constructing competencies rather than skills. Skills and competencies are similar, as they identify an individual's ability through experience and training. However, the functional level for acquiring a skill does not indicate the ability to perform it in the workplace where competency refers to the ability to fulfill the required behavior to achieve the desired results (Human Resource Systems Group [HRSG], 2018). 
Table 4: Education leadership master's programs offered by the top to ranked universities

\begin{tabular}{|c|l|l|l|}
\hline $\begin{array}{c}\text { QS ranking } \\
\mathbf{2 0 2 0}\end{array}$ & \multicolumn{1}{|c|}{ University } & \multicolumn{1}{|c|}{ Country } & Master's program in Education Leadership \\
\hline 1 & University College London & United Kingdom & Educational leadership \\
\hline 2 & Harvard University & United States & School leadership \\
\hline 3 & $\begin{array}{l}\text { Stanford } \\
\text { University }\end{array}$ & United States & Policy, organizational, and leadership studies \\
\hline 4 & University of Oxford & United Kingdom & $\begin{array}{l}\text { Does not offer a master's program in } \\
\text { education leadership }\end{array}$ \\
\hline 5 & $\begin{array}{l}\text { University of Toronto: OISE } \mid \text { Ontario } \\
\text { Institute for Studies in Education }\end{array}$ & Canada & Educational leadership and policy \\
\hline 6 & University of Cambridge & United Kingdom & Education leadership and school improvement \\
\hline 7 & The University of Hong Kong & Hong Kong SAR & School improvement and leadership \\
\hline 8 & $\begin{array}{l}\text { The University of California, Berkeley } \\
\text { (UCB) }\end{array}$ & United States & The principal leadership program \\
\hline 9 & University of British Columbia & Canada & $\begin{array}{l}\text { Educational administration and leadership } \\
\text { program (EDAL) }\end{array}$ \\
\hline 10 & Columbia University & United States & Education Leadership \\
\hline
\end{tabular}

Table 4 outlines the results of an audit of the master's programs offered by the top 10 ranked universities in education, as per the 2020 QS World Rankings. The results show that all these universities, except the University of Oxford, offer a master's program in educational leadership. A review of the marketing material on the program websites indicates that leadership encompasses a set of competencies that should be developed upon the completion of the programs. A summary of sample statements across websites highlights that these programs aim to prepare their candidates "to become an effective leader[s] of learning and change" (University College London [UCL], 2021); "to envision, enact, scale, and transform" (Harvard Graduate School of Education, 2021); to conduct "varied careers as leaders in the field of education" (Stanford: Graduate School of Education, 2021); to practice "leadership and learning in the context of school improvement and with reference to practice, policy, and theory" (University of Cambridge: Postgraduate Admissions, 2021); to "work successfully in diverse leadership roles across complex educational and schooling contexts and exercise their professional judgment in ways that perceive and promote the values of a civil, democratic, multicultural, and sustainable society, the empowerment of individuals and the wellbeing of communities" (University of British Colombia: Department of Educational Studies, 2021); and, finally, to "drive school improvement and . . . be held accountable for its success" (The Chinese University of Hong Kong: Faculty of Education, 2021).

The criterion behind selecting these programs was top-ranked universities offering a master's program in Education Leadership with a special focus on education reform and school improvement. The programs' missions indicate that they aim to equip program candidates with the necessary competencies to function in a complex, diverse environment and successfully execute transformation and improvement plans.

The programs' brief descriptions show some similarity and commonality among these programs, especially regarding main course themes. The University College of London (University College London [UCL], 2021) offers two master's programs in leadership, one for in-service leaders and the other for pre-service leaders. Both are one-year programs during which students undertake modules with a value of 180 credits, including two compulsory modules, two optional modules, and a 20,00o-word dissertation worth 60 credits each. The compulsory modules cover introduction to leadership in education, conducting research in the field of educational leadership and management, and a dissertation/report. The optional modules focus on leadership in the learning community and leadership in diverse cultures and communities.

In the United States, the selected programs adopted similar standards. The Graduate School of 
Education at Harvard University offers a master's program in school leadership (Harvard Graduate School of Education, 2021). The website promotes it as offering a rigorous but flexible curriculum that focuses on the school leader as a change agent. The courses cover a wide range of themes (e.g., management and finance, entrepreneurship, organizational change, and instructional leadership) with a total of 32 credits. Twelve credits in leadership cover topics such as leading change, race, equity, leadership, leading people, strategic leadership, fieldwork, and internships. These compulsory courses aim to provide candidates with opportunities to acquire knowledge and experience in the field of school leadership. Twelve and eight credits are specified as discipline and leadership electives, respectively.

Policy, Organization, and Leadership Studies (POLS), offered by the Graduate School of Education at Stanford University (Stanford: Graduate School of Education, 2021), is a nine-month full-time Master of Arts program. Students are required to complete 45 units within three consecutive semesters from autumn to spring. It is a flexible program in which academic preparation takes different forms: core and elective courses, seminars, workshops, and field practice. Students must also complete a field project to address a specific challenge in the major. The courses vary, covering qualitative and quantitative research designs, statistics, survey design, econometrics, research design, and data analysis. The field project is a cornerstone of the program; students must spend 150 hours over two semesters at sites such as a school, university, or other educational organization. By the end of the program, students must submit research reports, policy papers, or business plans. They are also required to share their experiences in the program by participating in a public seminar usually organized at the end of each academic year.

The Faculty of Education at Cambridge University, UK, offers a Master of Philosophy degree in the field of educational leadership and school improvement (University of Cambridge: Postgraduate Admissions, 2021). It is a 10-month, full-time, 96-credit-hour program that aims to provide candidates with unique opportunities to examine the theoretical frameworks used for studying the discipline of education and gain experience in different research methods appropriate to education. The courses offered are classified into two major themes: educational leadership, school improvement, and research methods. They focus on leadership for learning, education policy, school effectiveness and school improvement, perspectives on learning leadership and curricula, schools, cultures and communities, education evaluation, networks, and system leadership. In addition to the coursework, students are required to submit two essays: 4,00o words and 4,000-6,000 words, respectively. Ultimately, they submit a 15,00o-word dissertation, followed by an oral exam on the dissertation and essays.

The Master's in School Improvement and Leadership, Hong Kong University (The Chinese University of Hong Kong: Faculty of Education, 2021) is a two-year, part-time, course-based program, offered to educational practitioners committed to school improvement and leadership as Hong Kong schools are under tremendous pressure to improve the quality of their education system. Several initiatives have been introduced to achieve this target (e.g., school self-evaluation, external school reviews, and school-based management); consequently, school principals require certification to drive the school to excel academically. Educational leaders are responsible for improving school performance and are held accountable for their success. Schools are expected to align their programs with global trends and fulfill their local needs. Therefore, the master's program is designed to provide traditional and innovative school leaders with the required theoretical and applied knowledge and skills necessary to drive school improvement successfully. To graduate, candidates are required to complete 24 units. The study scope varies and includes core courses in the field, field practice, and guided improvement projects. The courses focus on advanced issues in school improvement, leadership for student learning, and the evaluation of school improvement.

The Department of Educational Studies at the University of British Columbia, Canada, offers two master's programs: MA and MEd degrees in Educational Administration and Leadership (University of British Colombia: Department of Educational Studies, 2021). The MA program is a twoyear thesis-based program. It also involves completing coursework worth 30 credits, which usually 
spans 10 courses. The courses are distributed among core courses covering leadership in educational organizations, leadership, administration, the aims of education, the study of organization in the educational context, methodology, and capstone courses covering research traditions in educational administration and group inquiry in education administration (Capstone project). The targeted candidates are those interested in expanding their educational leadership research experience and becoming educational researchers. The program also prepares students to complete their doctoral work in education ( $\mathrm{PhD}$ and EdD). The MEd degree is a one-year course-based program for experienced educators seeking to start a career in school leadership. Students must complete 30 credits of courses covering the same topics and fields as in the MA program.

Table 5: A comparative analysis of Master's programs in educational leadership at selected universities

\begin{tabular}{|c|c|c|c|c|c|c|c|c|c|}
\hline \multirow[t]{2}{*}{ Program Title } & \multirow[t]{2}{*}{$\begin{array}{l}\text { CH/ } \\
\text { Units }\end{array}$} & \multirow[t]{2}{*}{ Total } & \multirow[t]{2}{*}{$\begin{array}{c}\text { Duration } \\
\text { (One or two } \\
\text { years) }\end{array}$} & \multicolumn{6}{|c|}{$\begin{array}{l}\text { Graduation } \\
\text { requirements* }\end{array}$} \\
\hline & & & & $\mathrm{CW}$ & $\mathrm{TH}$ & & $\mathrm{E} \mid \mathrm{P}$ & $\mathrm{FE}$ & $\mathrm{CP}$ \\
\hline Educational leadership (UCL) & $\mathrm{CH}$ & 180 & 1 & $\sqrt{ }$ & $\sqrt{ }$ & $\times$ & $x \times$ & $x$ & $x$ \\
\hline School leadership (Harvard University) & $\mathrm{CH}$ & 32 & 1 & $\sqrt{ }$ & $x$ & 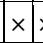 & $\times x$ & $\sqrt{ }$ & $x$ \\
\hline $\begin{array}{l}\text { Policy, organization, and leadership studies (Stanford } \\
\text { University) }\end{array}$ & Units & 45 & 1 & $\sqrt{ }$ & $x$ & $\sqrt{ } \mid>$ & $\times \sqrt{ }$ & $\sqrt{ }$ & $\sqrt{ }$ \\
\hline \begin{tabular}{|lll}
$\begin{array}{l}\text { Education leadership and School improvement } \\
\text { (University of Cambridge) }\end{array}$ & & \\
\end{tabular} & $\mathrm{CH}$ & 96 & 1 & $\sqrt{ }$ & $\sqrt{ }$ & $\times$ & $\sqrt{ } \mid \sqrt{ }$ & $x$ & $x$ \\
\hline $\begin{array}{l}\text { School improvement and leadership (Hong Kong } \\
\text { University) }\end{array}$ & Units & 24 & 2 & $\sqrt{ }$ & $x$ & $\times x$ & $\times x$ & $\sqrt{ }$ & $\sqrt{ }$ \\
\hline $\begin{array}{l}\text { Educational administration and leadership } \\
\text { program (EDAL) (University of British Columbia) }\end{array}$ & $\mathrm{CH}$ & 30 & 2 & $\sqrt{ }$ & $x$ & $\times$ & $\times \times$ & $x$ & $\sqrt{ }$ \\
\hline
\end{tabular}

* CW, coursework; TH, thesis; E, essays; R, report; P, presentation; FE, field experience; CP, capstone project

The data presented in Table 5 show that the reviewed programs focus primarily on coursework, with only two requiring the completion of a dissertation. However, they aim to prepare their candidates to continue their doctoral studies. The remaining four programs seek to prepare school leaders who can be change agents and lead their school through transformation. Therefore, students are required to spend considerable time in field practice and to design a capstone project.

The examination of the topics covered in the targeted programs shows that most of the courses lure prospective school leaders interested in acquiring the knowledge and competencies necessary for successful school transformation and school improvement by developing an unconventional framework for leadership practice grounded on the transition "from theory to practice, from parts to systems, from states and roles to process, from knowledge to learning, from individual action to partnership; and from detached analysis to reflexive understanding" (Taylor et al., 2002, p. 353).

\section{The theoretical framework of the enhanced Educational Administration Master Program}

The master's program proposed in this study aims at preparing school leaders conceptually, however, with more focus on practice. They are expected to effect changes in their schools. Table 6 presents the main characteristics of the proposed program. 
Table 6: Characteristics of the proposed joint Master's program in educational leadership and school improvement

\begin{tabular}{|c|c|c|c|c|c|c|c|c|c|}
\hline Program title & Type & Total CH & Duration & \multicolumn{4}{|c|}{ Graduation requirements* } \\
\hline Educational leadership and school improvement & $\mathrm{CH}$ & 36 & Two years & $\mathrm{CW}$ & TH & P & FW & CP \\
\hline
\end{tabular}

${ }^{*} \mathrm{CW}$, coursework; $\mathrm{TH}$, thesis; $\mathrm{P}$, presentation; FW, fieldwork; $\mathrm{CP}$, capstone project

The program should be flexible, diverse, and exciting. Coursework will be distributed among core and elective courses, seminars, and workshops. Core courses (12 credits) will cover areas of specialization as leadership and education organization behavior, leadership and change, and leadership and national/global citizenship. Fieldwork is fundamental for graduation; therefore, students must spend 150 hours over two semesters at sites such as schools, universities, or other educational organizations. Research methodology ( 6 credits) covers qualitative and quantitative research design, statistics, survey design, research design, and data analysis. General electives worth 6 credits cover seminars and workshops on different topics related to education leadership, school reform, and school improvement. Further, at the end of the second year, each student must submit a 15,000-word thesis and defend it.

The mission of the program will revolve around the following motto: "This program aims to equip prospective school leaders with the knowledge, theory, and the hands-on practice experience they need to lead, make positive changes required to fulfill the mission of school transformation and conduct measurable improvements."

Expected program learning outcomes:

By the end of the program, students will be able to develop the desired competencies that will enable them to become competent change agents who can design and execute transformation plans in their school as follows:

A. Instructional leadership learning competencies:

1. Facilitate student learning

2. Monitor and evaluate working staff teaching the subject

3. Use data to monitor school progress, identify problems, and make decisions

B. Distributed leadership competencies:

1. Develop and engage teachers in a collaborative professional culture to improve school performance

2. Develop and implement a hierarchical system of supervision and support to promote student success

3. Create an organizational culture for school staff to succeed as leaders, develop their leadership capacities, and conceptualize new meanings of leadership

C. Organizational leadership: candidates must demonstrate the ability to

1. Develop a consensus among staff about the school's goals

2. Set and implement a system for school discipline, enforcing consequences of misconduct

3. Understand effective management and communication skills to promote school operations

D. Cultural leadership: candidates must demonstrate the ability to

1. Promote a shared school vision and ethical commitment

2. Influence school change and improvement

3. Foster positive relationships and engagement with stakeholders and the local community

E. Human resources leadership: candidates must demonstrate the ability to

1. Develop teacher collaboration to achieve professional development for instructional knowledge and skills

2. Foster a professional learning community among school staff and faculty

3. Assist teachers in achieving their teaching goals and professional learning 


\section{Conclusion}

This study targeted to enhance the current Educational Administration Master Program offered in both Assiut and Kuwait Faculties of Education. These enhancements will foster and reinforce crossborder collaboration among staff members and graduate students in both countries. At the end of the day, these changes will help in training and preparing competent school leaders who can efficiently contribute to school transformation and improvement. Simultaneously, this program can serve as a foundation for future collaborative research projects in the field of educational leadership that can enrich the education literature and support the efforts of both countries to implement extensive education reform and comprehensive school improvement.

\section{References}

Abd El Razek, M. Y. (2019). The systems for teacher of English language education in England, Emirates, and Egypt: Comparative Study [Master's thesis]. School of Education, Mansoura University.

Acquaro, D. (2019). Preparing the next generation of educational leaders: Initiating a leadership discourse in initial teacher education. International Studies in Educational Administration (Commonwealth Council for Educational Administration \& Management (CCEAM)), 47(2), 107-124.

Adly, F. (2006). Leadership as a core of educational culture: Comparative study between governmental and civil society schools. Mustakbal al Tarbia al Arabia (The Future of Arabic Education), 42(12), 47-106.

Assiut University, (2016), Faculty of education. [Online] Available: http://www.aun.edu.eg/faculty_education /fac_history.php

Beatty, B. (2007). Going through the emotions: Leadership that gets to the heart of school renewal. Australian Journal of Education, 51(3), 328-340.

Bush, T. (2010). Leadership development. In T. Bush, L. Bell, \& D. Middlewood (Eds.), The principles of educational leadership and management. (2nd ed.). London: SAGE.

Bush, T., Kiggundu, E., \& Moorosi, P. (2011). Preparing new principals in South Africa: The ACE: School Leadership Programme. South African Journal of Education, 31(1), 31-43.

Carpenter, D. (2015). School culture and leadership of professional learning communities. International Journal of Educational Management, 29(5), 682-694.

Clark, A. J. (2017). Sustainable school improvement: Suburban elementary principals' capacity building. Journal for Leadership and Instruction, 16(1), 5-8.

Crow, G. M., \& Møller, J. (2017). Professional identities of school leaders across international contexts: An introduction and rationale. Educational Management Administration and Leadership, 45(5), 749-758.

Fullan, M. (2006). Change theory: A force for school improvement. Paper presented at the Center for Strategic Education (CSE), Seminar Series paper No. 157, Victoria, USA.

Gantasala, S., \& Omar, A. (2016). Examining cross-cultural leadership: Evidence from a UAE-based bank. Review of Contemporary Business Research, 5(1), 91-107.

Hallinger, P. (2005). Instructional leadership and the school principal: A passing fancy that refuses to fade away. Leadership and Policy in Schools, 4(3), 221-239.

Harris, A. (2004). Distributed leadership and school improvement: Leading or misleading. Educational Management and Administration, 32(1), 11-24.

Harris, A., \& Jones, M. (2019). Teacher leadership and educational change. School Leadership and Management, 39(2), 123-126.

Harris, A., \& Spillane, J. (2008). Distributed leadership through the looking glass. Management in Education, 22(1), 31-34.

Harris, D. R., \& Kemp-Graham, K. Y. (2017) The relationship between building teacher leadership capacity and campus culture. Education Leadership Review of Doctoral Research, 5, 49-74.

Harvard Graduate School of Education, (2021), Master's degree program: School leadership. [Online] Available: https://www.gse.harvard.edu/masters/slp

Huggins, K. S., Klar, H. W., Hammonds, H. L., et al. (2016). Supporting leadership development: An examination of high school principals' efforts to develop leaders' personal capacities. Journal of Research on Leadership Education, 11(2), 200-221.

Huggins, K. S., Klar, H. W., Hammonds, H. L., et al. (2017). Developing leadership capacity in others: An examination of high school principals' personal capacities for fostering leadership. International Journal of Education Policy and Leadership, 21(1), 1-15. 
Human Resource Systems Group (HRSG), (2018), What's the difference between skills and competencies? [Online] Available: https://resources.hrsg.ca/blog/what-s-the-difference-between-skills-and-competencies

i Solà, G. J., i Badia, J. G., Delgado-Hito, P., et al. (2016). Self-perception of leadership styles and behaviour in primary health care. BMC Health Services Research, 16, 1-9.

Jackson, K. M., \& Marriott, C. (2012). The interaction of principal and teacher instructional influence as a measure of leadership as an organizational quality. Educational Administration Quarterly, 48(2), 230-258.

Kelley, R. C., Thornton, B., \& Daugherty, R. (2005). Relationships between measures of leadership and school climate. Education, 126(1), 17-25.

Khondker, H. (2004). Glocalization as globalization: Evolution of a sociological concept. Bangladesh e-Journal of Sociology, 1(2).

Leithwood, K. (2009). Distributed leadership according to the evidence. New York: Routledge.

Leithwood, K., Louis, K. S., Anderson, S., et al., (2004), Executive summary: How leadership influences student learning. [Online] Available: https://www.wallacefoundation.org/knowledge-center/Documents/HowLeadership-Influences-Student-Learning.pdf

Leithwood, K., Louis, K. S., Anderson, S., et al. (2004). How leadership influences student learning: A review of research for the learning from leadership project. New York: Wallace Foundation.

Leithwood, K., Mascall, B., \& Strauss, T. (2009). Distributed leadership according to the evidence. London: Routledge.

Leithwood, K., \& Sun, J. (2012). The nature and effects of transformational school leadership: A meta-analytic review of unpublished research. Educational Administration Quarterly, 48(3), 387-423.

Leithwood, K., \& Riehl, C. (2003). What do we already know about successful school leadership. AERA: Division A: Task Force on Developing Research in Educational Leadership, 1-6o.

McCullough, M., Lipscomb, S., Chiang, H., \& Gill, B., et al. (2016). Do principals' professional practice ratings reflect their contributions to student achievement? Evidence from Pennsylvania's Framework for Leadership. Working Paper 46. Mathematica Policy Research, Inc.

NCATE, (2008), Professional standards for the accreditation of teacher preparation institutions. [Online] Available: http://caepnet.org/ /media/Files/caep/accreditation-resources/ncate-standards-20o8.pdf?la=en

Price, J. (2017). The construction of cultural leadership. ENCATC Journal of Cultural Management and Policy, 7(1), 5-16.

QS Top Universities, (2020), QS World University Rankings: Education. [Online] Available: https://www.topuniversities.com/university-rankings/university-subject-rankings/2020/education-training

Saavedra, J., (2019), Shaking up Egypt's public education system. Education for Global Development. [Online] Available: https://blogs.worldbank.org/education/shaking-egypts-public-education-system

Sartori, G. (1970). Concept misformation in comparative politics. American Political Science Review, 64(4), 10331053.

Schein, E., (2013), Edgar Schein: Organizational culture and leadership. [Online] Available: https://thehypertextual.com/2013/o1/17/edgar-schein-organizational-culture-and-leadership/

Solomon, A., \& Steyn, R. (2017). Leadership styles: The role of cultural intelligence. SA Journal of Industrial Psychology, 43(1), 1-12.

Spillane, J. P., Halverson, R., \& Diamond, J. B. (2004). Towards a theory of leadership practice: A distributed perspective. Journal of Curriculum Studies, 36(1), 3-34.

Stanford: Graduate School of education, (2021), Policy organization and leadership studies (POLS). [Online] Available: https://ed.stanford.edu/pols/about

Sturgis, K., Shiflett, B., \& Tanner, T. (2017). Do leaders' experience and concentration area influence school performance? Administrative Issues Journal: Education, Practice, and Research, 7(1), 107-121.

Taylor, M., De Guerre, D., Gavin, J., et al. (2002). Graduate leadership education for dynamic human systems. Management Learning, 33(3), 349-369.

Teh, B., Chiang, H., Lipscomb, S., et al., (2014), Measuring school leaders' effectiveness: An interim report from a multiyear pilot of Pennsylvania's Framework for Leadership (REL 2015-058). [Online] Available: http://ies.ed.gov/ncee/edlabs

Teichler, U. (1996). Comparative higher education: Potentials and limits. Higher Education, 32(4), 431-465.

The Chinese University of Hong Kong: Faculty of Education, (2021), MA Degree in school improvement \& leadership. [Online] Available: https://www.fed.cuhk.edu.hk/higherdegree/programme/ma-degree-inschool-improvement-leadership/

Tsivgiouras, S., Belias, D., Velissariou, E., et al. (2017). Educational leadership and school culture - The role of the school leader. 
University College London (UCL), (2021), Educational leadership MA. [Online] Available: https://www.ucl.ac.uk/prospective-students/graduate/taught-degrees/educational-leadership-ma

University of British Colombia: Department of Educational Studies, (2021), Educational administration and leadership (EDAL). [Online] Available: https://edst.educ.ubc.ca/programs/educational-administrationleadership/

University of Cambridge: Postgraduate Admissions, (2021), MPhil in education (Educational leadership and school improvement). [Online] Available: https://www.postgraduate.study.cam.ac.uk/courses/directory/ededmpe ls

Webb, D. O. (2014). The relationship between principal leadership and teacher morale in the elementary schools in a northwest Georgia school district [Doctoral dissertation] Liberty University.

Williams, S. (2018). Developing the capacity of culturally competent leaders to redress inequitable outcomes: Increasing opportunities for historically marginalized students. Administrative Issues Journal: Education, Practice, and Research, 8(1), 48-58. 